\title{
Gap junctions in hematopoietic stroma control proliferation and differentiation of blood cell precursors
}

\author{
ESTEVÃO BODI ${ }^{1}$, SANDRA P. HURTADO ${ }^{2}$, MARCELO A. CARVALHO ${ }^{2}$ \\ RADOVAN BOROJEVIC ${ }^{2,3}$ and ANTÔNIO C. CAMPOS DE CARVALHO ${ }^{1}$ \\ ${ }^{1}$ Instituto de Biofísica Carlos Chagas Filho, CCS, Bl. G, Universidade Federal do Rio de Janeiro \\ Cidade Universitária, Ilha do Fundão, 21949-900 Rio de Janeiro, RJ, Brasil \\ ${ }^{2}$ Departamento de Histologia e Embriologia, Instituto de Ciências Biomédicas \\ Universidade Federal do Rio de Janeiro, 21949-900 Rio de Janeiro, RJ, Brasil \\ ${ }^{3}$ PABCAM, Hospital Universitário Clementino Fraga Filho \\ Universidade Federal do Rio de Janeiro, Cidade Universitária, Ilha do Fundão \\ 21941-970 Rio de Janeiro, RJ, Brasil \\ Manuscript received on April 7, 2004; accepted for publication on May 26, 2004; \\ contributed by ANTONIO C. CAMPOS-DE-CARvalHo*
}

\begin{abstract}
We examined gap junction communication in an in vitro model of hematopoiesis, using the murine bone marrow stroma cell line S-17, and primary cultures of murine marrow-derived blood cell precursors. S-17 cells express several connexins, the major one being connexin 43. Connexin expression and formation of functional gap junctions is modulated by stroma cell density. Transfection of S-17 cells with a vector containing connexin 43 sense or anti-sense sequences increased or decreased, respectively, connexin 43 synthesis and intercellular dye coupling. Under these conditions, modulation of gap junction-mediated communication modified the growth pattern of stroma itself, as well as the ability of the stroma to sustain hematopoiesis. Increased connexin 43 expression was associated with a delay in differentiation of blood cells, resulting in increased production of hematopoietic precursors, while decreased connexin 43 expression elicited an accelerated differentiation of myeloid blood cell precursor cells. These results suggest that connexin-mediated coupling in the stroma modulates the ratio between proliferation and differentiation of hematopoietic precursors. We therefore propose that increased gap junction communication in the stroma elicits an enhanced production of immature bone marrow cells through the delay in their terminal differentiation, inducing consequently an extended proliferation period of blood cell precursors.
\end{abstract}

Key words: bone marrow, hematopoiesis, connexins, Gap junctions, S-17 cells.

\section{INTRODUCTION}

Gap junctions are specialized cell membrane structures that form ion channels interconnecting the cytoplasm of adjacent cells. The intercellular channels are formed by apposition of hemi-channels or

\footnotetext{
*Member Academia Brasileira de Ciências

Correspondence to: Antonio Carlos Campos de Carvalho

E-mail: acarlos@biof.ufrj.br
}

connexons, each one made of six protein sub-units belonging to the connexin family (Makowski et al. 1977). Nineteen members of the family have been cloned in rodents, and named according to the molecular weights in $\mathrm{kDa}$ of the proteins predicted from their cDNAs, e.g. connexin 43, or Cx43 (Manthey et al. 1999). Molecules of up to $1 \mathrm{kDa}$ can pass through gap junctions, thus allowing for the rapid 
diffusion of metabolites or second messengers between cells of a given tissue. The control of intercellular communication mediated by gap junctions is achieved by processes such as trans-junctional potential, intracellular calcium and $\mathrm{pH}$ levels, as well as connexin phosphorylation. Despite the fact that gap junctions are usually not present in circulating blood cells, connexin expression is known to occur in leukocytes during inflammatory reactions in blood vessels (Saez et al. 2000), and gap junctions have been described in the hematopoietic bone marrow (Rosendaal et al. 1991, Rosendaal 1995).

Hematopoiesis is a highly ordered biological phenomenon. Approximately $2 \times 10^{11}$ blood cells belonging to several lineages are produced each day in a normal adult human. Each cell lineage has a relatively independent pattern of production, which can promptly respond to specific peripheral demands. All the lineages are derived from a small population of totipotent hematopoietic stem cells, which follow a programmed progressive restriction of their proliferating capacity, ultimately generating the terminally differentiated mature blood cells. In chronological terms, the early part of the proliferation cascade involves the generation of totipotent or multipotent cells, while the later one produces the most differentiated cells (Johnson 1984). At each step of this cascade, hematopoietic cells respond in a different manner to various growth factors, cytokines, or inhibitors of proliferation and differentiation present in the bone marrow environment. Consequently, chronological order of hematopoiesis is spatially ordered, providing a defined microenvironment to the cells that are at a specific developmental stage, inducing the next step of their commitment and differentiation (Metcalf 1993).

It has been shown that the intramedullar hematopoietic space is divided in logettes, organized around a central vascular loop, and delimited by the bone tissue covered by endosteum (Charbord et al. 1996). The most immature cells are located close to the endosteum, and the maturation is concomitant with their migration towards the central region, in which they reach the blood vessels and are even- tually released into the systemic circulation (Lord 1997). This spatial order requires the presence of internal gradients, recognized and followed by blood cell precursors during their proliferation and maturation. These gradients are of short range, since the distance from the endosteum to the central blood vessel is not large, and they have to be modulated in accordance with the increased or decreased peripheral demand for one or another cell type. Since the spatial organization of the hematopoietic environment is dependent upon the local connective tissue stroma, its cells are integrated into multicellular units that have to be recognized and correctly interpreted by blood precursors along their migration, proliferation and differentiation.

Recent studies have presented morphological evidence for the presence of gap junctions in the membranes of both stroma and blood cell lineages. Cytochemical analyses of bone marrow have consistently shown the presence of the $\mathrm{Cx} 43$ in the stroma and Cx37 in bone marrow blood vessels (Krenacs and Rosendaal 1998). Intercellular transfer of dyes such as Lucifer Yellow (LY) among stroma cells, and more rarely between the stroma and the blood cell precursors, have been demonstrated, indicating the presence of functional gap junctions (Rosendaal et al. 1991, Dorshkind et al. 1993). In humans Cx43 has been shown to mediate coupling between bone marrow stromal cells and CD34+ blood cell precursors (Durig et al. 2000). Observations, both in vivo and in vitro, have suggested that $\mathrm{Cx} 43$ expression can be low during the steady state production of blood cells in adults, but its high expression is critical for periods of enhanced blood production in embryogenesis and regeneration after cytoablative treatments (Rosendaal 1995, Krenacs and Rosendaal 1998, Rosendaal et al. 1994). Studies on cell lines derived from Cx43 knockout animals that were transfected with $\mathrm{Cx} 43$ cDNA confirmed the supportive role for gap junction communication in hematopoiesis (Cancelas et al. 2000). In another study hematopoiesis in mice knockout for $\mathrm{Cx} 43$ was shown to be deficient in both lymphopoiesis and myelopoeisis (Montecino-Rodriguez et al. 2000). 
Notwithstanding the description of connexins and functional gap junctions in hematopoietic tissues, and altered hematopoiesis in knockout mice, the precise role played by gap junction communication in hematopoiesis has been elusive. The caveats of the proposal that gap junctions participate in the control of hematopoiesis are (a) that stroma cells can regulate the degree of their gap junction-mediated communication in response to external demands, and (b) that modulation of gap junction-mediated intercellular communication can induce altered patterns of hematopoietic cell proliferation and differentiation. We therefore undertook this study to address the issue of whether specifically modulating gap junction expression in stroma cells resulted in altered blood cell production.

\section{MATERIALS AND METHODS}

\section{Cell Cultures}

The S-17 murine bone marrow stroma cell line was established and described by Dorshkind et al. (1986). Cells were obtained from the Rio de Janeiro Cell Bank (PABCAM, Federal University of Rio de Janeiro) and used with authorization obtained from Dr. K. Dorshkind. S-17 cells were maintained in Dulbecco's Modified Minimum Essential Medium (DMEM) (GIBCO-BRL, Gaithersburg, MD) supplemented with $10 \%$ fetal bovine serum (FBS) (Cultilab, Campinas, SP, Brazil) without antibiotics. Bone marrow hematopoietic cells were harvested by flushing the femoral cavity of inbred C57BL/10J mice with the culture medium. Cells were gently dissociated with a Pasteur pipette, plated in plastic Petri dishes (Nunc, Roskilde, Denmark), and incubated at $37^{\circ} \mathrm{C}$. After 2 hours, non-adherent cells were harvested, quantified and used for further experiments. Confluent S-17 and transfected S-17 cells plated over plastic coverslips in 24-well tissue culture plates (Nunc), were co-cultured with $10^{5}$ hematopoietic non-adherent cells per well obtained from the same mice. Hematopoietic cells were harvested daily, and cytosmears were prepared by cyto-centrifugation. The cells were fixed with methanol and stained by standard May-Grünwald and Giemsa (MGG) solutions (Gabe 1968). The stroma cells remaining attached on coverslips were fixed and stained as described.

\section{Dye Transfer Experiments}

Cells were plated in $35 \mathrm{~mm}$ Petri dishes, and injected with LY, as previously described (Froes et al. 1999). Two minutes after the injection into one cell, the adjacent cells that received the dye were observed under fluorescence microscopy and counted. All dye transfer experiments used cells at the same passage and at the same stage of confluence.

\section{IMMUNOCYTOCHEMISTRY}

Cells were plated in 24-well plates, over $13 \mathrm{~mm}$ glass coverslips. The cells were fixed in $70 \%$ ethanol at $-20^{\circ} \mathrm{C}$ for 20 minutes. Non-specific binding was blocked using a solution of $0.1 \%$ bovine serum albumin (BSA) in phosphate-buffered saline (PBS). Cells were treated with a polyclonal anti-Cx43 antibody directed to residues 346-360 of the Cx43 sequence (kindly supplied by E. Hertzberg - Albert Einstein College of Medicine, New York, USA), diluted 1:250 in blocking solution containing BSA $(5 \%)$ in PBS, at $37^{\circ} \mathrm{C}$ for 1 hour. Cells were subsequently incubated with fluoresceine isothiocyanate (FITC)-conjugated anti-rabbit IgG (Sigma Chemical Co, St. Louis, MO) diluted 1:500 in PBS under the same conditions. Mouse heart tissue was used as a positive control for $\mathrm{Cx} 43$ labeling and liver was used as negative control.

\section{Reverse Transcriptase - Polymerase Chain REACTION (RT-PCR) ANALYSIS}

Total RNA was extracted from $10^{6}$ cells using TRIZOL (GIBCO-BRL) according to the manufacturer's protocol. RNA $(1 \mu \mathrm{g})$ was reverse-transcribed using a cDNA synthesis kit (Pharmacia, Uppsala, Sweden), at $37^{\circ} \mathrm{C}$ for 1 hour. The cDNAs were amplified using 22 cycles for $\beta$-actin and 25 cycles for the connexins $\left(30\right.$ seconds at $94^{\circ} \mathrm{C}, 90$ seconds at $58^{\circ} \mathrm{C}, 2$ minutes at $72^{\circ} \mathrm{C}$, and finally 10 minutes at 
TABLE I

Connexins Primers for RT-PCR experiments.

The position of the primer in mRNA is displayed between brackets.

\begin{tabular}{|c|c|c|}
\hline Foward & Reverse & RT-PCR Product \\
\hline $\begin{array}{l}\text { Cx26 (284) } \\
\text { 5'tggcctaccggaagacacga }\end{array}$ & $\begin{array}{l}\text { Cx26 (586) } \\
\text { 5'caaattccagacacagagat }\end{array}$ & $302 \mathrm{pb}$ \\
\hline $\begin{array}{l}\text { Cx } 30.3(343) \\
\text { 5'gccetgtacagcaacctgag }\end{array}$ & $\begin{array}{l}\text { Cx } 30.3 \text { (783) } \\
\text { 5'gtcatggatacacacetgca }\end{array}$ & $440 \mathrm{pb}$ \\
\hline $\begin{array}{l}\text { Cx } 31 \text { (257) } \\
\text { 5'gtccctctatgetggtcatc }\end{array}$ & $\begin{array}{l}\text { Cx } 31 \text { (694) } \\
\text { 5'ctcgctaatcctgtggaag }\end{array}$ & $373 \mathrm{pb}$ \\
\hline $\begin{array}{l}\text { Cx } 31.1 \text { (328) } \\
\text { 5'gtgaaggttacetttacccg }\end{array}$ & $\begin{array}{l}\text { Cx } 31.1 \text { (630) } \\
\text { 5'tctttgctaggagagttggc }\end{array}$ & $366 \mathrm{pb}$ \\
\hline $\begin{array}{l}\text { Cx } 32 \text { (376) } \\
\text { 5'cacatctcagggacactgtg }\end{array}$ & $\begin{array}{l}\text { Cx } 32 \text { (712) } \\
\text { 5'ttgtattcaggtgagaggcg }\end{array}$ & $336 \mathrm{pb}$ \\
\hline $\begin{array}{l}\text { Cx } 33 \text { (378) } \\
\text { 5'ggcgcttgcagaaacataca }\end{array}$ & $\begin{array}{l}\text { Cx } 33 \text { (819) } \\
\text { 5' caccgggactacctgatcac }\end{array}$ & $441 \mathrm{pb}$ \\
\hline $\begin{array}{l}\text { Cx } 37 \text { (391) } \\
\text { 5'gaacatcagatggccaagat }\end{array}$ & $\begin{array}{l}\text { Cx } 37 \text { (1504) } \\
5 \text { 'ggatcataaacagtggaact }\end{array}$ & $1113 \mathrm{pb}$ \\
\hline $\begin{array}{l}\text { Cx } 40 \text { (291) } \\
\text { 5'gcacactgtgcgcatgcagg }\end{array}$ & $\begin{array}{l}\text { Cx } 40(1021) \\
5 ' \text { ctgctggcettactaaggcg }\end{array}$ & $730 \mathrm{pb}$ \\
\hline $\begin{array}{l}\text { Cx } 43(514) \\
5 \text { 'atccagtggtacatctatgg }\end{array}$ & $\begin{array}{l}\text { Cx } 43 \text { (1087) } \\
\text { 5'ctgctggctctgctggaagg }\end{array}$ & $573 \mathrm{pb}$ \\
\hline $\begin{array}{l}\text { Cx } 45(265) \\
5 \text { 'gtgatgtacctgggatatgc }\end{array}$ & $\begin{array}{l}\text { Cx } 45 \text { (855) } \\
5 \text { 'cttagcattggacagctcag }\end{array}$ & $590 \mathrm{pb}$ \\
\hline $\begin{array}{l}\text { Cx } 46 \text { (375) } \\
\text { 5'ggaaccaatgcgtacaggga }\end{array}$ & $\begin{array}{l}\text { Cx } 46(925) \\
5 \text { 'cctctgccttgcgcatcgtt }\end{array}$ & $550 \mathrm{pb}$ \\
\hline $\begin{array}{l}\text { Cx } 50(301) \\
5 \text { 'cgcatggaggagaagcgcaa }\end{array}$ & $\begin{array}{l}\text { Cx } 50(853) \\
\text { 5'gggctggtctccaccat }\end{array}$ & $593 \mathrm{pb}$ \\
\hline
\end{tabular}

$72^{\circ} \mathrm{C}$ ). Products were separated by electrophoresis in $2 \%$ agarose gels and stained with Ethidium Bromide. A mock-RT-PCR reaction, in which the reverse transcriptase was omitted during the preparation of cDNA from the cell RNA, was used as the internal negative control for the potential presence of the genomic DNA. This reaction was always negative and it is not displayed in the Figures.

The sequences for connexin primers are given in Table I. Specific primer sequences were used for each connexin tested. Their specificity was checked by running controls for each primer with all connexin cDNAs used.
In semi-quantitative PCR experiments $1 \mu \mathrm{g}$ cDNA was used in 10-fold serial dilutions (1:1000; $1: 100 ; 1: 10$ and $1: 1)$. PCR products were quantified by densitometry and $\mathrm{Cx} 43$ expression was compared to that of $\beta$-actin.

\section{WESTERN-BLOTS}

Cells grown to confluence in $60 \mathrm{~mm}$ Petri dishes were harvested in $1 \mathrm{mM} \mathrm{NaH} \mathrm{CO}_{3}$ buffer ( $\mathrm{pH}$ 8.3) containing $2 \mathrm{mM}$ phenylmethylsuphonyl fluoride (PMSF), $1 \mathrm{mM} \mathrm{Na} \mathrm{VO}_{4}$ and $5 \mathrm{mM}$ ethylenediaminetetraacetic acid (EDTA). The sample was sonicated, protein content was estimated by Bradford's 


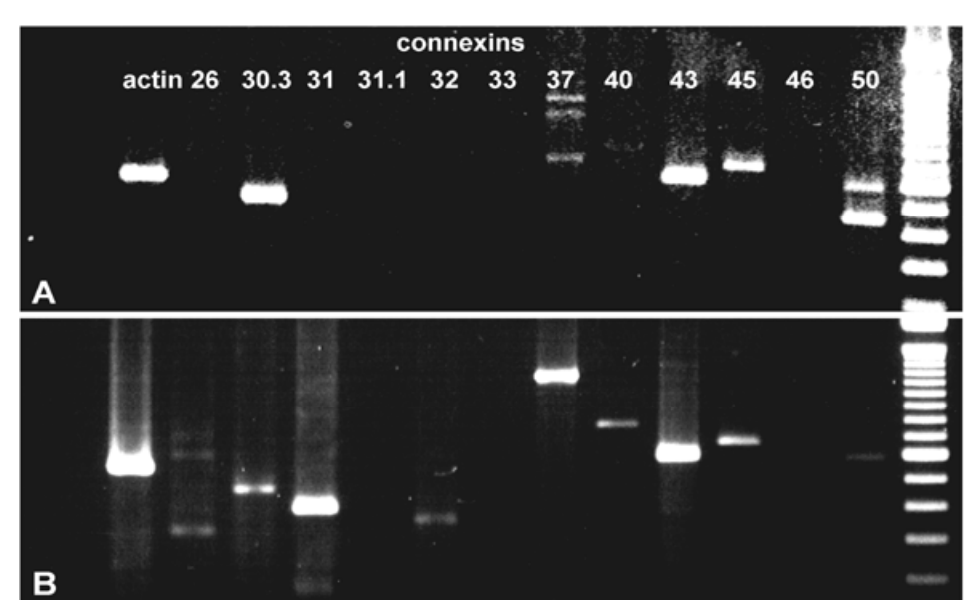

Fig. 1 - RT-PCR analysis of connexin expression in S-17 cells. RT-PCR was done using the primers listed in Table I. The expression of mRNA for Cxs 30.3, 37, 43, 45 and 50 was found in S-17 cells in pre-confluence (A). When cultures became confluent, mRNAs for Cxs. 26, 30.3, 31, 32, 37, 40, 43, 45 were detected (B).

method, and $20 \mu \mathrm{g}$ of protein were submitted to SDS-PAGE and then transferred to nitro-cellulose membranes ( $0.2 \mu \mathrm{m}$ pore, SIGMA). The membranes were blocked with 5\% skim milk in PBS for 20 minutes at room temperature and incubated for one hour with the polyclonal anti-Cx43 IgG (described in immunocytochemistry), which recognizes both phosphorylated and unphosphorylated $\mathrm{Cx} 43$, diluted 1:2500 in 5\% skim milk in PBS. The membranes were reacted with alkaline phosphataseconjugated anti-rabbit IgG (Sigma) diluted 1:2000 in 5\% skim milk in PBS, for one hour at room temperature, and developed with NBT/BCIP. Densitometric analysis (Kodak Digital Science 1D) was performed in blots.

\section{DNA Constructs And Transfection}

PBIL vectors containing the entire rat $\mathrm{Cx} 43$ sense (PB-Cx43) or anti-sense coding sequences (PBantiCx43) were kindly donated by Dr. David C. Spray (Albert Einstein College of Medicine, New York). The plasmid orientations were checked by restriction patterns (data not shown). S-17 cells were transfected with $\mathrm{PB}-\mathrm{Cx} 43$, PB-antisense Cx43 or PB plasmid alone, using Lipofectamine
(GIBCO-BRL) following the manufacturer's instructions. After 48 hours, cells were incubated in selection medium: DMEM, with $10 \%$ FBS and $800 \mu \mathrm{g} / \mathrm{mL} \mathrm{G}-418$ (GIBCO-BRL). Cells were maintained under selection for at least two weeks, changing the medium every 3 days. When no dead cells were present in cultures (three weeks), the cells were used for the experiments.

\section{RESULTS}

\section{Connexin Expression and Functional Gap}

Junctions in the Murine Hematopoietic

Stroma Cell Line S-17

The murine bone marrow stroma-derived S-17 cell line sustains both human and murine hematopoiesis in vitro (Dorshkind et al. 1986, Hao et al. 1998). Under proliferating conditions S-17 cells express a fibroblastoid phenotype, converting to a continuous monolayer of polygonal cells after reaching confluence, when the cells are fully contact-inhibited. Connexin expression was monitored in early confluence and post-confluence of S-17 cultures. RTPCR analysis of the cells showed the presence of transcripts for several connexins in early conflu- 
ence (Fig. 1A) and at confluence (Fig. 1B). Semiquantitative RT-PCR indicated up-regulation of Cx43 message after confluence (Fig. 2). Westernblot and immunofluorescence also showed the presence of Cx43 (Fig. 3). Western-blotting confirmed up-regulation of total $\mathrm{Cx} 43$ content in post-confluent cell cultures (Fig. 3A). The latter method indicated that in early confluence low levels of $\mathrm{Cx} 43$ were essentially present in the cytoplasm (Fig. 3B), whilst after two days of confluence, the typical punctuate distribution along the cell membranes at the interface between adjacent cells was observed (Fig. 3C). The presence of other connexins identified by RTPCR could not be detected by use of available antibodies (anti-Cx26, Cx32 and 37 antibodies, data not shown).

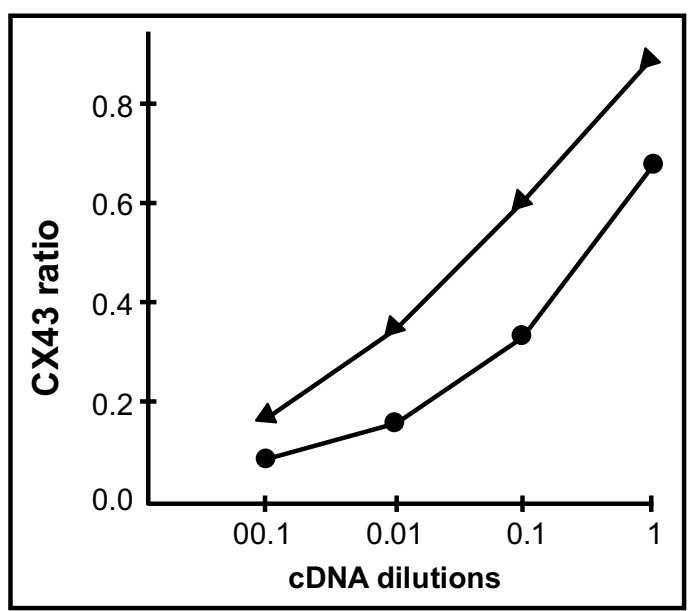

Fig. 2 - Semi-quantitative RT-PCR for $\mathrm{Cx} 43$, using serial ten fold dilutions (1:1000, 1:100, 1:10 and 1$)$ of $1 \mu \mathrm{g}$ cDNA. Results represent the ratio between $\mathrm{Cx} 43$ and $\beta$-actin expression in $\mathrm{S} 17$ cells, in early-confluent cultures $(\bullet)$ and in full confluence $(\boldsymbol{\Delta})$.

The presence of functional gap junctions was monitored by LY transfer. In agreement with the expression pattern of $\mathrm{Cx} 43$, dye transfer was very low in early confluence (Fig. 4A,B), and high after the cells had reached confluence (Fig. 4C,D).
Biological Function of Cx43 Gap JunCtions IN THE Hematopoietic Stroma

In order to establish the biological role of gap junction mediated cell coupling in the hematopoietic stroma, we proceeded to transfect S-17 cells with the PBIL vector, the vector containing the sense sequence corresponding to $\mathrm{Cx} 43 \mathrm{mRNA}$, or the vector containing the anti-sense sequence. The expression of $\mathrm{Cx} 43$ in the three transfected cell lines was monitored by dye coupling and immuno-labeling techniques. Western blot analysis showed the expected decrease in $\mathrm{Cx} 43$ expression in cells transfected with anti-sense sequence, and an increase in cells transfected with the sense vector (Fig. 5).

Gap junction mediated coupling, as determined by intercellular LY transfer, was in agreement with Cx43 expression (Fig. 6), showing that increased or decreased availability of $\mathrm{Cx} 43$, in the sense and anti-sense transfected cells, correlated with the presence of functional gap junctions. S-17 cells transfected with plasmid only exhibit coupling comparable to untransfected cells, and intermediate between anti-sense and sense transfected cells (histograms in Fig. 6). We were thus able to monitor whether modulation of coupling and connexin-43 expression had an effect on the in vitro growth pattern of S-17 cells. Plasmid-transfected cells followed a growth pattern similar to control cells. Cx43 antisense-transfected cells had a tendency to spread on the plastic substrate, while sense-transfected cells grew in a typical pattern of "hills-and-valleys", characteristic of myofibroblasts, in which cells show a tendency to adhere to each other more than to the culture dish surface (Fig. 7). Primary cultures of both human and murine bone marrow stroma cells display this pattern of growth.

\section{EFFect of Gap Junction-mediated Stroma Cell Coupling on Hematopoiesis}

Hematopoietic stroma controls the proliferation and differentiation of hematopoietic precursors through cell-cell contacts involving adhesion, as well as juxtacrine and/or paracrine stimulation of membrane- 

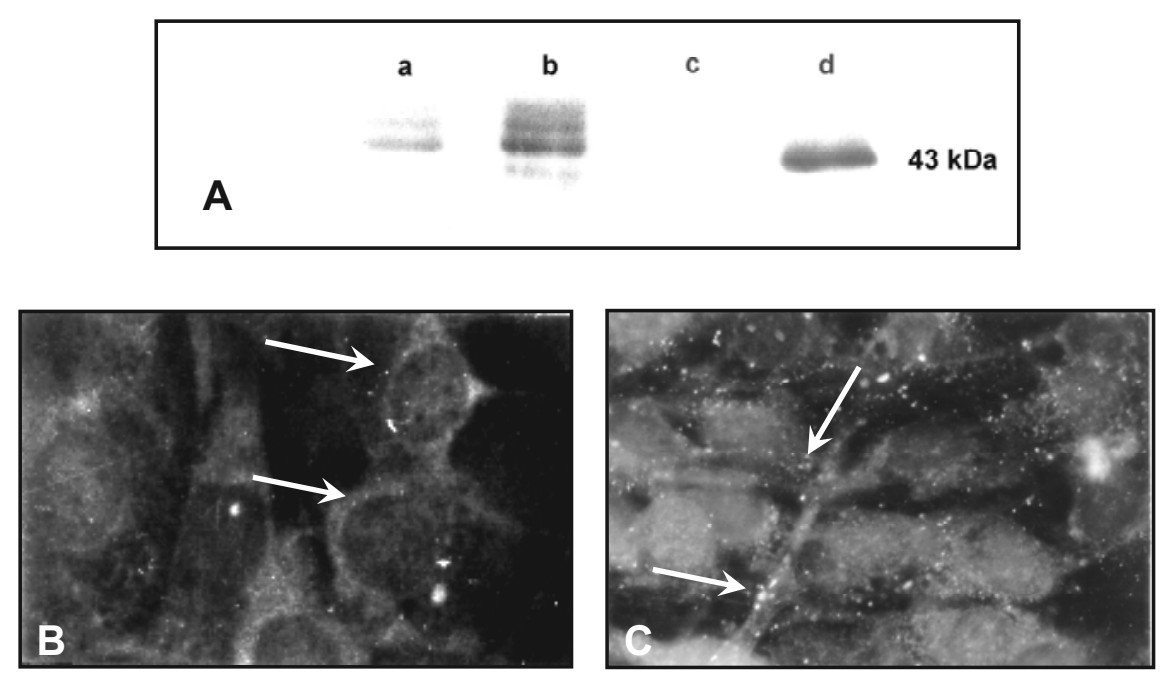

Fig. 3 - (A) Expression of Cx43 in S-17 cells: total protein extracted from cells (15 $\mu \mathrm{g})$ was loaded in each lane and the blot was probed with a polyclonal antibody specific for $\mathrm{Cx} 43$ (residues 346-360). Lane a shows S-17 cells in pre-confluence, lane b in confluence, lane $\mathrm{c}$ is a negative control using mouse liver tissue and $\mathrm{d}$ a positive control using mouse brain tissue. Observe the lower expression of $\mathrm{Cx} 43$ in the pre-confluent S-17 cultures and the higher expression in confluent cells. (B) Immunocytochemistry, using the Cx43 antibody, shows the diffuse labeling of Cx43 in the cytoplasm of pre-confluent S17 cells and (C) punctuate pattern of labeling at appositional membrane areas in confluent cultures of S17 cells. Magnification $=\times 400$.

receptors on the target cells. The capacity of S-17 cells to sustain hematopoiesis was monitored by coculture with freshly harvested non-adherent murine bone marrow cells. This cell fraction contains hematopoietic precursors in different stages of commitment and differentiation, which respond to stimulation either by further proliferation or by expression of the terminally differentiated phenotype. In blood cells, the full differentiation is associated with the cessation of proliferation. Under the experimental conditions used in our study only myelopoiesis is favored.

Control cultures over the normal S-17 cells and cultures over S-17 cells transfected with plasmid only showed a similar ability to sustain myelopoiesis. The general pattern of myelopoiesis over the S17 stroma transfected with plasmid containing the anti-sense sequence for $\mathrm{Cx} 43$, with a decreased gap junction-mediated coupling, was char- acterized by and accelerated terminal differentiation of myeloid cells (Fig. 8). Mature granulocytes and macrophages derived from the donor bone marrow could be observed for up to $24 \mathrm{~h}$ after co-culture (Fig. 8A). Myeloid cells were still dividing, forming small clusters of cells whose central region contained cells with a relatively high nucleo/cytoplasmic ratio, and the cytoplasm with high affinity for MGG stains characteristic of myeloid precursors. From the second day on (Figs. 8B and C), most myeloid cells acquired a lower nucleus/cytoplasmic ratio and lower affinity for MGG stains, characteristic of the macrophage morphology in vitro. Some cells with macrophagic morphology were still able to divide (Fig. 8B, arrow). From the third day of culture (Figs. 8D and E) all the cells differentiated forming small ( $<20$ cells) clusters or isolated mono-macrophagic cells, with the morphological conversion into macrophages with a low nucleus- 

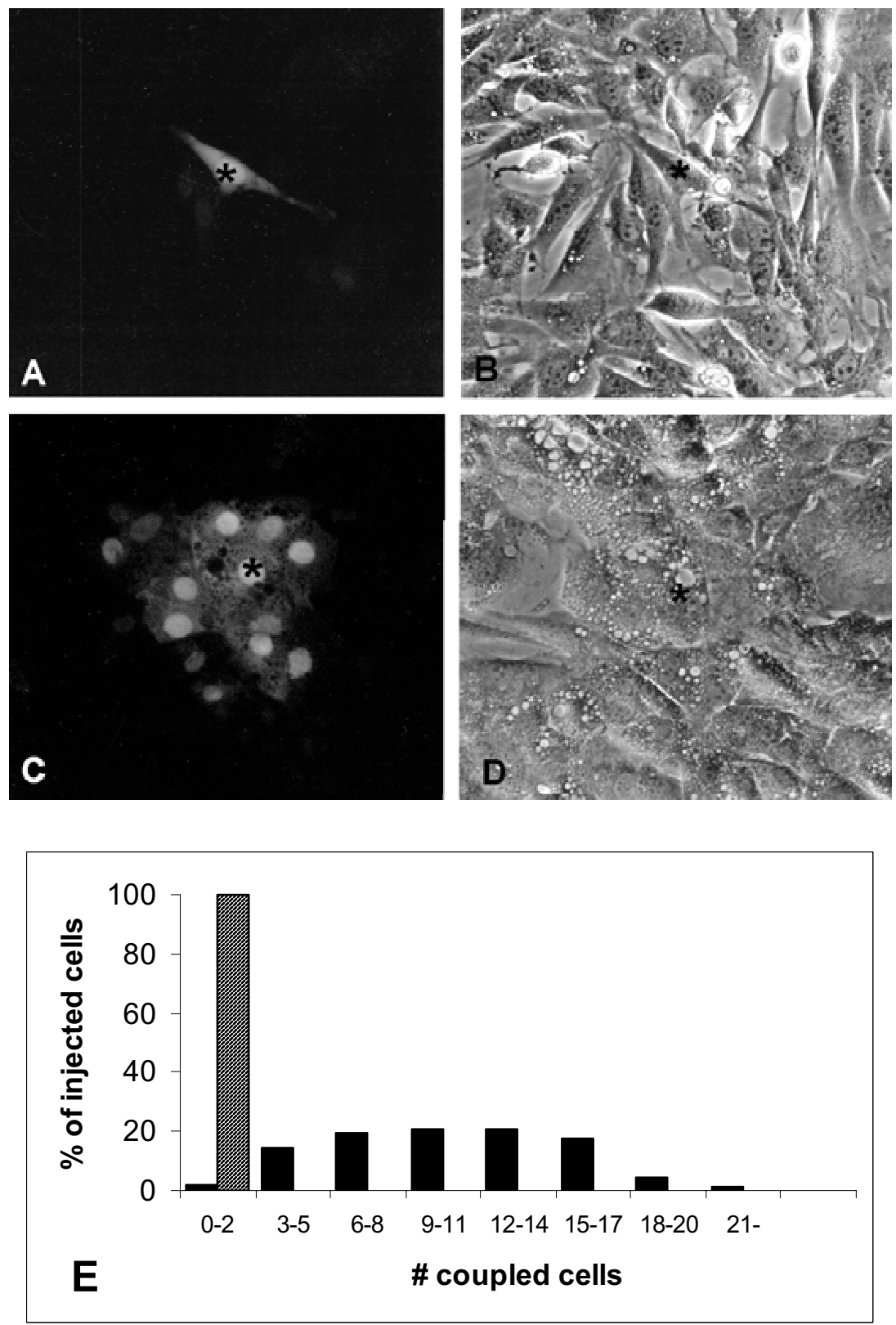

Fig. 4 - Functional coupling between S-17 cells in early-confluence (A and B) and in postconfluence (C and D). The level of coupling in S-17 cells was determined by dye-transfer experiments using Lucifer Yellow (LY). S-17 cells in early-confluence displaying a fibroblastoid morphology are not coupled - LY is retained in the cell in which it was injected (marked with asterix). In post-confluent cultures cells show a polygonal form, vacuolated cytoplasm (D), and a significant degree of gap-junction coupling as indicated by the spread of LY to adjacent cells (C). Magnification $=\times 320$. (E) Histogram showing degree of coupling in post-confluent cultures (filled bars) and early confluent cultures (hatched bar). 


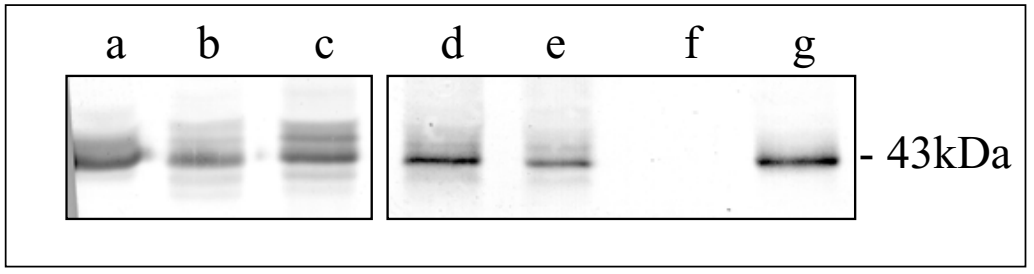

Fig. 5 - Expression of Cx43 in S-17 cells transfected with sense Cx43, anti-sense Cx43 DNA and plasmid only. Proteins were extracted ( $20 \mu \mathrm{g}$ total protein) after cells reached confluence. Western blot of mouse brain (positive control) is shown in lane a, S-17 cells transfected with the anti-sense Cx43 is shown in the lane b, and sense Cx43 in lane c. In another experiment S-17 cells were transfected with plasmid only (lane d), and with anti-sense Cx43 (lane e). Mouse liver was used as a negative control in lane $\mathrm{f}$, and mouse brain as positive control in lane $\mathrm{g}$.
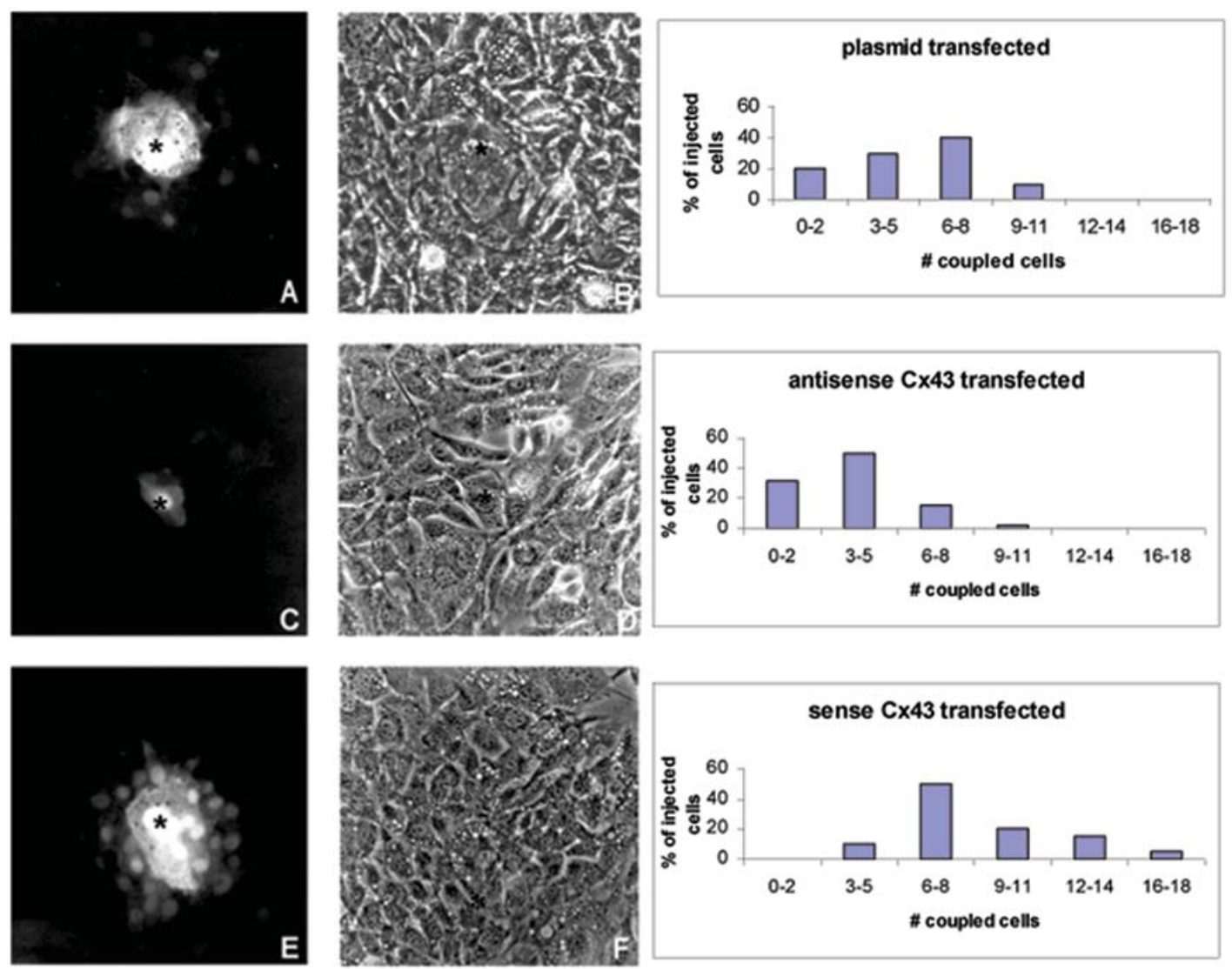

Fig. 6 - Functional coupling among confluent cultures of S-17 cells transfected with plasmid only (A and B), anti-sense (C and D) and with sense (E and F) for $\mathrm{Cx} 43$. Cells transfected with anti-sense $\mathrm{Cx} 43$ exhibit low coupling level. S-17 cells transfected with $\mathrm{Cx} 43$ in sense orientation show enhanced coupling. Histograms of the degree of coupling are displayed in right panel. 

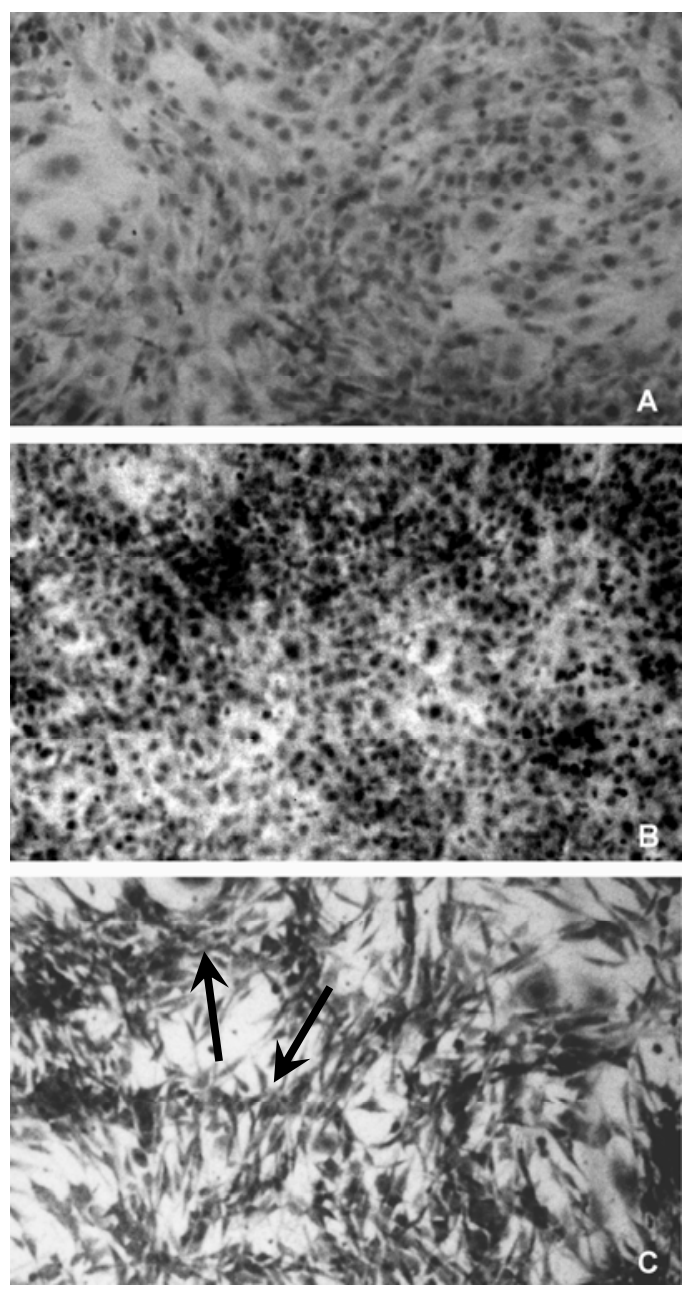

Fig. 7 - Morphology of S-17 cells used as a stroma layer for cocultures with non-adherent bone marrow cells, as observed after harvesting the bone marrow cells. A. S-17 cells transfected with the plasmid without any insert. B. S-17 cells transfected with the plasmid containing the anti-sense sequence for Cx43. C. S-17 cells transfected with the plasmid containing the sense sequence for $\mathrm{Cx} 43$. Note the typical "hills and valleys" pattern of growth in C (arrows). Final magnification $\times 120$.

cytoplasmic ratio and a vacuolated cytoplasm. From the fifth day on (Figs. 8F and $\mathrm{H}$ ) all the cells were differentiated into mature vacuolated macrophages, remaining either isolated or still gathered in small groups. Apoptotic figures were frequent, and low cell proliferation was concomitant with the in- creased cell debris, characteristic of senescent cultures (Fig. 8H).

The effect of increased gap junction-mediated coupling was monitored in cultures of myeloid cells over the stroma of S-17 cells transfected with the plasmids containing sense Cx43 DNA (Fig. 9). The S17 cells transfected with the sense DNA delayed myeloid cell differentiation, and after $24 \mathrm{~h}$ of culture clusters of immature myeloid cells were found without any morphological signs of differentiation (Fig. 9A). After 48 and $72 \mathrm{~h}$ of culture (Figs. 9B to D) the size of the clusters increased due to the continuous proliferation of myeloid cells, forming giant colonies of undifferentiated cells that grew up for over six days in culture (Figs. 9E and F). From this moment on, their differentiation into macrophages proceeded from the periphery to the center of the colonies. Maturing macrophages could be clearly observed at the periphery (Fig. 9G), or progressively detached and after eight days the large colonies fragmented into smaller clusters that still contained blasts in the center. On the eight-day, granulocytes whose life in culture is inferior to $24 \mathrm{~h}$ were still found, indicating the sustained production of GM$\mathrm{CSF}$, and indicating that the manipulation of $\mathrm{Cx} 43$ expression did not inhibit the fundamental ability of S-17 cell to sustain the full differentiation of myeloid lineages.

\section{DISCUSSION}

In the present study, we have shown, in an in vitro experimental model of hematopoiesis, that a bone marrow stroma cell line expresses several connexins, the major one being $\mathrm{Cx} 43$, and forms functionally competent gap junctions. We also demonstrated that the two conditions required to causally correlate the presence of functional gap junctions to the control of hematopoiesis were present, namely (a) modulation of connexin expression in the stroma was biologically relevant for stroma growth pattern and function, and (b) in vitro hematopoiesis was modulated by connexin expression and the presence of functional gap junction channels. 

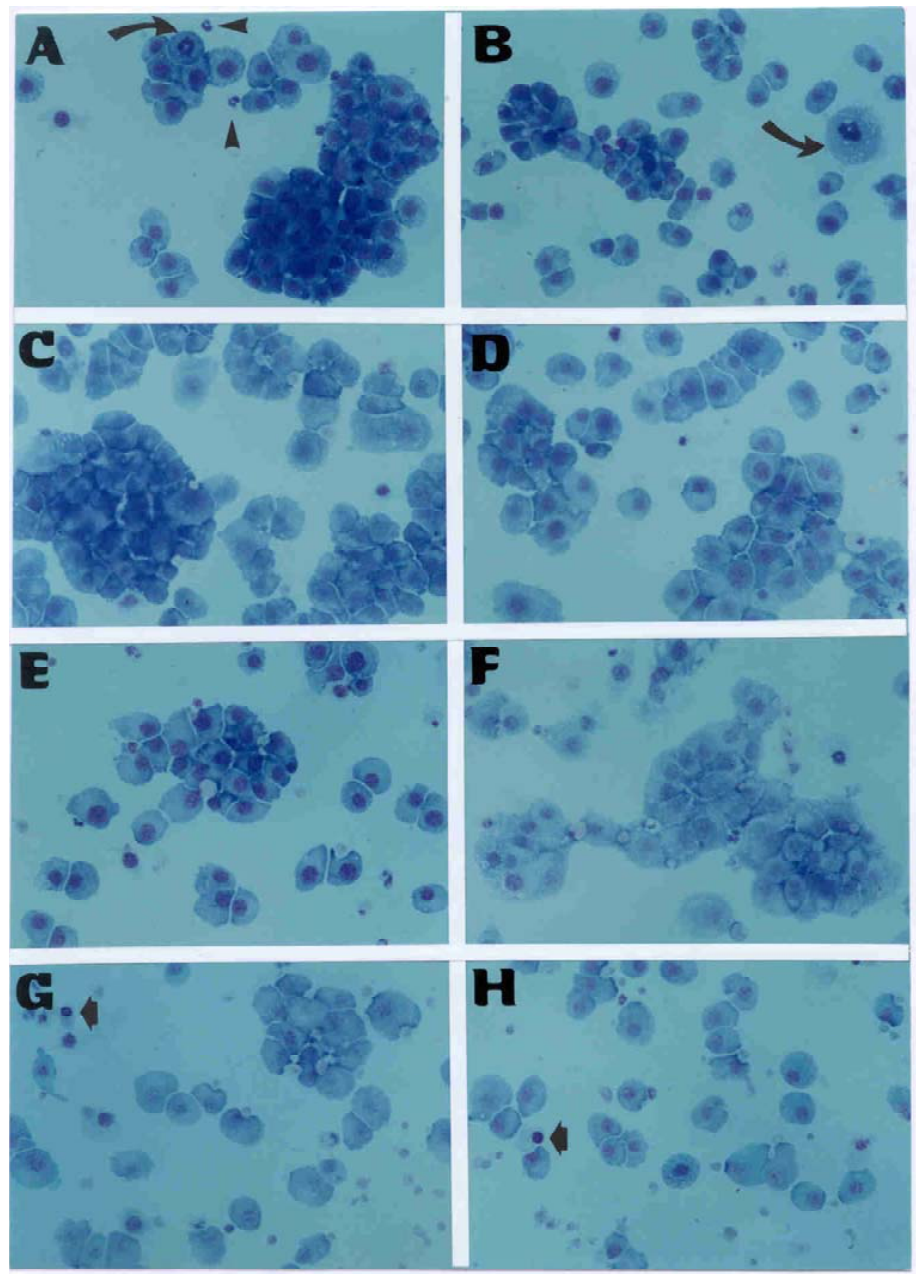

Fig. 8 - Growth and differentiation of murine non-adherent bone marrow cells maintained over S-17 cells transfected with the vector containing the antisense sequence for $\mathrm{Cx} 43$. Murine non-adherent bone marrow cells were maintained in co-culture, harvested and stained after 1 day (A), 2 days (B), 3 days (C and D), 4 days (E), 5 days (F), 6 days (G) and 7 days (H). Arrow head in A points to granulocytes, arrows in A and B indicate macrophage-like cells in division, arrows in $\mathrm{G}$ and $\mathrm{H}$ indicate apoptotic cells. Final magnification $\times 500$.

$\mathrm{Cx} 43$ expression in stroma cells was modulated both at the level of transcription and translation and this modulation was dependent upon cell density. Parallel studies have shown that hormones, such as corticoids, and vitamin A, agents known to control myeloid cell differentiation, also modulate connexin expression in the hematopoietic stroma (Hurtado et al. 2004). In our experimental model, the level of stroma cell coupling was determinant of the pattern of hematopoietic cell proliferation and differentiation. In agreement with in vivo data obtained by the group of Rosendaal (Rosendaal 1995, Krenacs and Rosendaal 1998, Dorshkind et al. 1993), and with observations on Cx43 knockout mice (Montecino- 

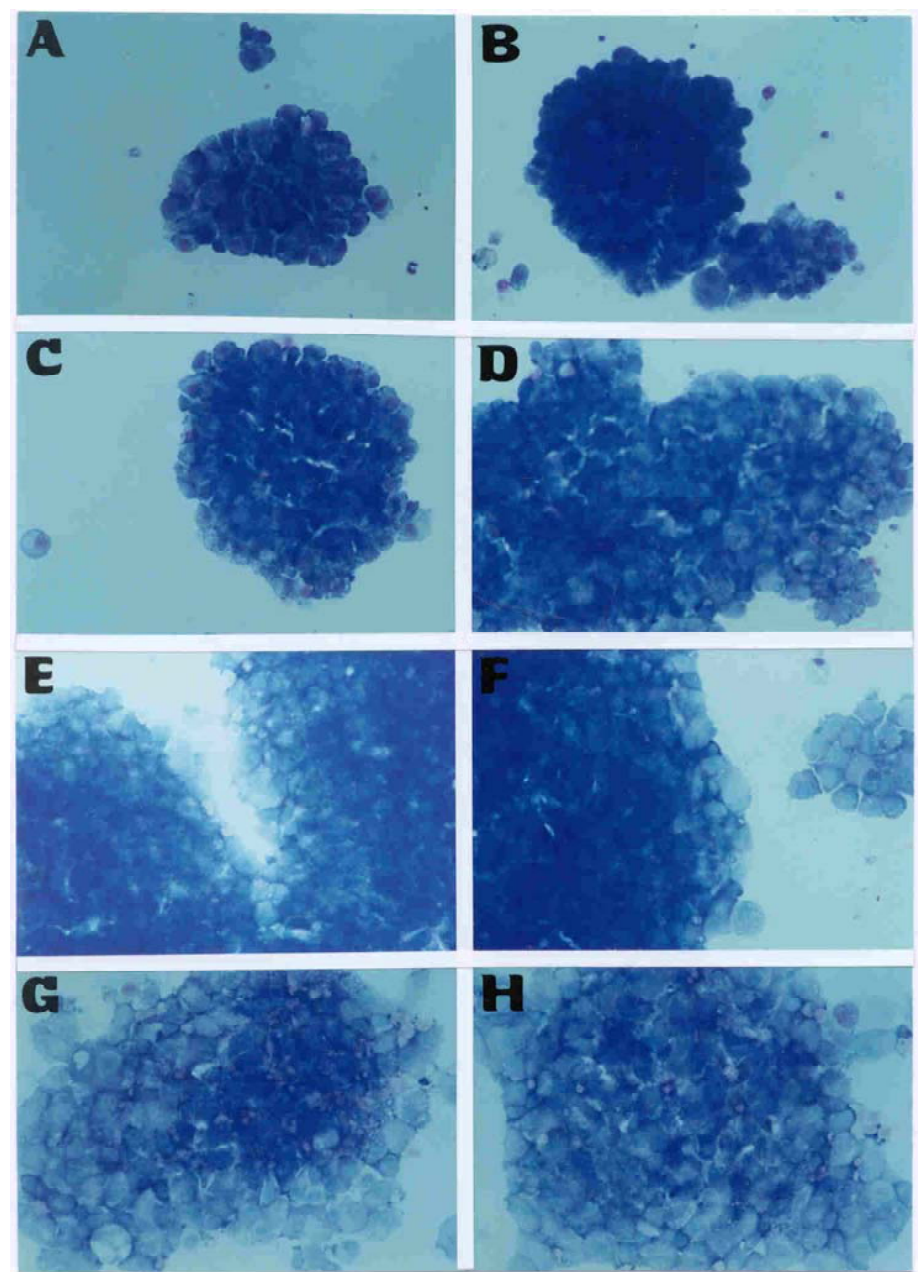

Fig. 9 - Growth and differentiation of murine non-adherent bone marrow cells maintained over S-17 cells transfected with the vector containing the sense sequence for $\mathrm{Cx} 43$. Murine non-adherent bone marrow cells were maintained in co-culture, harvested and stained after 1 day (A), 2 days (B), 3 days (C and D), 5 days $(\mathrm{E}$ and $\mathrm{F}), 7$ days $(\mathrm{G})$ and 8 days $(\mathrm{H})$. Final magnification $\times 500$.

Rodriguez et al. 2000), we also observed that the increase of the overall hematopoietic cell output was associated with increased expression of $\mathrm{Cx} 43$. Furthermore, not only the expression of $\mathrm{Cx} 43$ seemed to be relevant but also the degree of gap junction mediated intercellular coupling (GJIC). In that regard our results are in line with those reported by Cancelas et al. (2000), whom demonstrated a decreased hematopoietic activity in fetal liver stroma cell lines derived from Cx43 KO mice. Importantly, re-introduction of the $\mathrm{Cx} 43$ gene in the $\mathrm{KO}$ cell lines not only re-established dye coupling to normal levels but also increased hematopoietic supporting activity of the fetal stroma cell line (Cancelas et al. 2000). Interestingly, Cx32 KO mice are less capable of supporting hematopoiesis in vivo (Hirabayashi H., personal communication). The ability to simultaneously examine the variation in $\mathrm{Cx} 43$ expression and 
the GJIC is important given the growing evidence for connexin mediated effects that are not dependent on cell-to-cell communication (Goldberg et al. 2000). Our in vitro system, using the sense and anti-sense strategy to up or down-regulate $\mathrm{Cx} 43 \mathrm{ex}$ pression and GJIC clearly indicates that $\mathrm{Cx} 43$ modulation of hematopoiesis is dependent on stroma cell-to-cell communication. It remains to be seen if stroma-hematopoietic junctional communication is also modulated under our experimental conditions. At any rate, our results suggest that modulation of stroma GJIC affects primarily hematopoietic cell differentiation, speeding it when stroma cells are poorly coupled and delaying it when stroma cells are highly coupled. High proliferation rates in this later case would ensue, since each additional division between the early committed precursors and terminally differentiated blood cells doubles the total cell output.

Our findings are also in accordance with the proposal that the subendosteal layer and the adjacent reticular cells are integrated through gap junctions (Rosendaal et al. 1991). In this region are located the earliest blood cell precursors that are maintained in the undifferentiated state. In order to achieve their full maturation, the cells have to leave the subendosteal environment, and migrate towards the central perivascular part of the bone marrow, in which there are no gap junctions and which favor the cell differentiation (Rosendaal et al. 1991). Gap junctions may mediate the integration of hematopoietic microenvironments, and give a molecular support to the concept of intrinsic spatial gradients in the bone marrow, in which the cells are exposed to the favorable condition for proliferation or differentiation at the specific stage of their differentiation, for a limited period of time.

The question of how gap junctions determine these microenvironments and the involved signals remains open, and this question is the subject of ongoing studies. At any rate, the data presented suggests that hematopoiesis may be controlled through two parallel and probably complementary mechanisms. In the first one, the systemic factors and hor- mones brought into the bone marrow by blood circulation, as well as the locally produced cytokines, act directly on hematopoietic cells proper, through interaction with the corresponding receptors. In the second one, hematopoiesis can respond to peripheral demands or suffer intrinsic modifications indirectly, through modulation of cell coupling in the stroma, and the consequent modification of blood precursor adhesion, proliferation and differentiation.

\section{ACKNOWLEDGMENTS}

This work was supported by grants from Programa de Apoio a Núcleos de Excelência (PRONEX), Conselho Nacional de Desenvolvimento Científico e Tecnológico (CNPq), Financiadora de Estudos e Projetos (FINEP), Fundação de Amparo à Pesquisa do Estado do Rio de Janeiro (FAPERJ), Fundação Universitária José Bonifácio (FUJB) and the International Centre for Genetic Engineering and Biotechnology, Trieste. Estevão Bodi had a fellowship from Fundação de Amparo à Pesquisa do Estado de São Paulo (FAPESP) (97/04863-9).

\section{RESUMO}

Investigamos a comunicação intercelular mediada por junções comunicantes em um modelo in vitro de hematopoiese, usando uma linhagem celular murina de estroma de medula óssea, S-17, e culturas primárias de precursores hematopoiéticos murinos. As S-17 expressam diversas conexinas, sendo a principal a conexina43. A expressão de conexinas e a formação de canais funcionais são moduladas pela densidade das células de estroma. A transfecção de células S-17 com um vetor contendo seqüências senso ou anti-senso de conexina43 aumenta ou diminui, respectivamente, a síntese de conexina43 e o acoplamento intercelular. Nestas condições, a modulação da comunicação mediada pelas junções comunicantes modifica o padrão de crescimento das células do próprio estroma, bem como a capacidade do estroma para sustentar a hematopoiese. O aumento na expressão de conexina43 resulta em um retardo na diferenciação das células sanguíneas, e no aumento da produção de precursores hematopoiéticos, enquanto a diminuição na expressão da conexina43 resulta numa diferenciação acelerada dos precursores mielóides. Estes resultados sugerem que o acoplamento mediado por conexina nas células de estroma modula a razão entre proliferação e diferenciação dos precursores hematopoiéti- 
cos. Propomos portanto, que o aumento da comunicação mediada por junções comunicantes no estroma elicita uma produção aumentada de células imaturas de medula óssea, através de um retardo em sua diferenciação terminal, induzindo consequentemente um período de proliferação prolongado dos precursores hematopoiéticos.

Palavras-chave: medula óssea, hematopoiese, conexinas, junções comunicantes, células S-17.

\section{REFERENCES}

Cancelas JA, Koevoet WLM, de Koning AE, Mayen AEM, Rombouts EJC and Pleomacher RE. 2000. Connexin-43 gap junctions are involved in multiconnexin-expressing stromal support of hemopoietic progenitors and stem cells. Blood 96: 498-505.

Charbord P, Tavian M, Humeau L and Péault B. 1996. Early ontogeny of the human marrow from long bones: an immunohistochemical study of hematopoiesis and its microenvironment. Blood 87: 4109-4119.

Dorshinind K, Johnson A, Collins L, Keller GM and PHILlips RA. 1986. Generation of purified stromal cell cultures that suport lymphoid and myeloid precursors. J Immunol Methods 89: 37-47.

Dorshrind K, Green L, Godwin A and Fletcher WH. 1993. Connexin 43 type gap junctions mediate communications between bone marrow stromal cells. Blood 82: 38-45.

Durig J, Rosenthal C, Halfmeyer K, Wiemann M, Novotny J, Bingmann D, Duhrsen U and SCHIRRMACHER K. 2000. Intercellular communication between bone marrow stromal cell and CD34+ haematopoietic progenitor cells is mediated by connexin 43-type gap junctions. Br J Haematol 111: 416-425.

Froes MM, Correia AHP, Garcia-Abreu J, Spray DC, Carvalho ACC and Moura Neto V. 1999. Gap junctional coupling between neurons and astrocytes in primary central nervous system cultures. Proc Natl Acad Sc. USA 96: 7541-7546.

Gabe M. 1968. Techniques Histologiques, ed. Masson, Paris.

Goldberg GS, Bechberger JF, Tajima Y, Merrit M, OMORI Y, GaWinowicz MA, Narayanan R, TaN Y, Yamasaki H, Naus CC, Tsuda H and Nicholson BJ. 2000. Connexin43 supresses MFG-E8 while inducing contact inhibition of glioma cells. Cancer Res 60: 6018-6026.
HAO GL, SMOgORZEWSKa EM, BARSKY LW AND CROOKS GM. 1998. In vitro identification of single CD34+ CD38- cells with both lymphoid and myeloid potential. Blood 91: 4145-4151.

Hurtado S, Balduino A, Bodi E, El-Cheikh MC, Campos de Carvalho AC and Borojevic R. 2004. Connexin expression and gap-junction-mediated cell interactions in an in vitro model of haemopoietic stroma. Cell Tissue Res 316: 65-76.

JoHNSON GR. 1984. Hematopoietic multipotential stem cells in culture. Clin. Haematol. 13: 309-327.

Krenacs T and Rosendaal M. 1998. Connexin43 gap junctions in normal, regenerating, and cultured bone marrow and in human leukemias: their possible involvement in blood formation. Amer J Pathol 152: 993-1004.

LORD B. 1997. Biology of the hematoopoietic stem cell. In: Potten CS. (Ed.) Stem cells. Academic Press, London, pp. 401-422.

Makowski L, Caspar DLD, Phillips WC and GoodeNOUGH DA. 1977. Gap junctions structure II: Analysis of the X-ray diffraction data. J Cell Biol 74: 629-645.

Manthey D, Bakauskas F, Lee CG, Kozak CA and WiLLECKE K. 1999. Molecular cloning and functional expression of the mouse gap junction gene connexin 57 in human HeLa cells. J Biol Chem 274: 14716-14723.

MetCalf D. 1993. Hematopoietic regulators: redundance or subtlety? Blood 82: 3515-3523.

Montecino-Rodriguez E, Leathers H and DorshKIND K. 2000. Expression of connexin 43 (Cx43) is critical for normal hematopoiesis. Blood 96: 917-924.

RosendaAl M. 1995. Gap junctions in blood forming tissues. Microscop. Res Techn 31: 396-407.

Rosendaal M, Gregan A and Green CR. 1991. Direct cell-cell communication in the blood forming system. Tissue Cell 23: 457-470.

Rosendaal M, Green CR, Rahman A and Morgan D. 1994. Up-regulation of the connexin 43 gap junction network in haematopoietic tissue before the growth of stem cell. J Cell Sci 107: 29-37.

Saez JC, Branes mC, Corvalan LA, Egenin EA, Gonzalez H, Martines AD and Palisson F. 2000. Gap junctions in cells of the immune system: structure, regulation and possible functional roles. Braz J Med Biol Res 33: 447-455. 